OPEN ACCESS

Edited by:

Rui Liu,

Southwest Petroleum University,

China

Reviewed by: Pei Li,

SINOPEC Petroleum Exploration and Production Research Institute, China Mengdi Sun, Northeast Petroleum University, China

*Correspondence: Fuping Zhao DB20010022B4CX@cumt.edu.cn Zhiyao Zhang 1075231995@qq.com

Specialty section: This article was submitted to

Economic Geology, a section of the journal Frontiers in Earth Science

Received: 26 October 2021 Accepted: 01 December 2021

Published: 10 January 2022

Citation:

Lan B, Zhao F, Li S, Jiang H, Liu S and Zhang $Z$ (2022) Investigation of the

Enrichment and Accumulation of Normal Pressure Shale Gas in Anchang Syncline Outside of

Sichuan Basin.

Front. Earth Sci. 9:802142. doi: 10.3389/feart.2021.802142

\section{Investigation of the Enrichment and Accumulation of Normal Pressure Shale Gas in Anchang Syncline Outside of Sichuan Basin}

\author{
Baofeng Lan ${ }^{1,2}$, Fuping Zhao ${ }^{2,3 *}$, Shaopeng $\mathrm{Li}^{1}$, Haishen Jiang ${ }^{1}$, Song Liu ${ }^{1}$ and \\ Zhiyao Zhang ${ }^{4 *}$
}

${ }^{1}$ Wujiang Energy Group Company Guizhou Energy Industry Research Institute Co., Ltd, Guiyang, China, ${ }^{2}$ Key Laboratory of Unconventional Natural Gas Evaluation and Development in Complex Tectonic Areas, Ministry of Natural Resources, Guizhou, China, ${ }^{3}$ School of Resources and Geosciences, China University of Mining and Technology, Xuzhou, China, ${ }^{4}$ Key Laboratory of Tectonics and Petroleum Resources of Ministry of Education, China University of Geosciences, Wuhan, China

Gas shales from the Wufeng-Longmaxi Formation in Anchang syncline in northern Guizhou area of Sichuan Basin are stable in distribution and can be classified as type I shale gas reservoir with great resource potential. The exploration and development of shale gas in Anchang syncline have achieved great progress. However, the enrichment rule and accumulation pattern of shale gas in Anchang syncline are still not clear at the present. Gas pressure in the Wufeng-Longmaxi Formations shales in Anchang syncline is normal. The maximum tested gas production in the field ranges from 18,000 to $58,000 \mathrm{~m}^{3} / \mathrm{d}$. However, gas production of shale wells varies greatly even in the same platform. In order to understand the shale gas enrichment and accumulation and improve the effective development of shale gas in this area, comparative analyses on the geological characteristics and preservation conditions of gas reservoirs in several typical wells were carried out from the perspective of geology, petrophysics, geophysics, and well logging. Results show that shale gas in Anchang syncline has the characteristics of accumulating in both deep central position and gently wings. Tectonic preservation condition is the key factor to high gas production in Anchang area. The hydrological conditions, syncline structure, fault distribution, and cap rock quality comprehensively control the gas pressure and gas bearing capacity of shale reservoir. According to these factors, an accumulation model of shales with normal gas pressure is established: syncline controls the distribution of gas reservoir; fault controls the boundary of the reservoir; preservation conditions controls gas capacity. The results are benefit for the rolling exploration and development of shale gas in Anchang area, and are important for the development of normal pressure shale gas in northern Guizhou area.

Keywords: shale, northern guizhou, normal pressure, enrichment rule, accumulation model, preservation conditions 


\section{INTRODUCTION}

With the growing demand for energy, unconventional oil and gas have gradually become the hotspots of fossil energy development (Jarvie et al., 2007; Hao et al., 2013; Rezaee, 2015; Xu et al., 2019). In recent years, shale gas exploration and development have achieved great progress in China. Specifically, shale gas from the Sichuan basin and its peripheral areas have stepped into the stage of commercial development (i.e., Fuling block, Changning-Weiyuan block, and Zhaotong blocks). At the same time, the geology theory and engineering technology of shale gas are gradually becoming mature. According to the exploration and development practice of shale gas in Jiaoshiba area, many researchers have summarized and proposed the dual-element enrichment rule of marine shale gas: the developed high-quality shale in deep water shelf is the basis of hydrocarbon generation, and the good preservation condition is the key to reservoir formation and production of shale gas (Guo, 2013; Guo and Zhang, 2014; Jin et al., 2016). He et al. (2019) analyzed the main controlling factors for the enrichment and high yield of atmospheric shale gas in the complicated tectonic region in southeast Chongqing, and believed that shale gas enrichment was controlled by various factors such as the preservation conditions of sedimentary facies and in situ stress field (Xiao et al., 2015). Based on the exploration practice of shale gas in the Wufeng-Longmaxi Formation in Sichuan Basin and its surrounding areas, many researchers argued that the distribution and enrichment of shale gas reservoirs with normal pressure were obviously controlled by the tectonic movements (Xu et al., 2020a, 2020b; Fang and He, 2016; Zheng et al., 2019; Huang et al., 2017; Zumberge et al., 2012; Bai et al., 2013. These observations effectively support the rapid development of marine shale gas in China.

The lower Silurian Longmaxi shale in Sichuan Basin is dominated by overpressure or ultra-high pressure shale gas reservoirs, while the vast areas outside the Sichuan Basin are dominated by normal pressure shale gas reservoirs. Compared with the overpressure shale gas which has entered the commercial development stage, the distribution area of normal pressure shale gas is wider than the overpressure shales. Thus, the exploration and development potential of normal pressure shale gas is huge in China. Marine shales of Wufeng-Longmaxi Formation, which have the greatest exploration and development potential in south China, are characterized by normal gas pressure in most areas. Many shale gas reservoirs in North America are also atmospheric, such as the Antrim shale, Fayetteville shale, and Barnett non-core shale plays (Curtis, 2002; Zagorski et al., 2012; Aguilera, 2016). However, the formation mechanism and effective development model of normal pressure shale gas reservoirs remain unclear.

Based on the data of geological data, seismic, drilling, and gas content tests in Anchang syncline, this paper analyzed the geological characteristics of Anchang syncline shale gas reservoir and compared them among different typical wells. It is found that the hydrologic conditions, synclinal structure, fault distribution, and quality of cap rock comprehensively control the pressure distribution and gas content of shale reservoir. The shale gas distribution has the typical characteristics of gas accumulating in gentle wings and enriching in central parts. An accumulation model of shale gas is proposed: synclines control the reservoir area, faults control the edge of reservoir, and preservation controls the gas content. It is beneficial for the effective exploration and development of shale gas in this area and other vast syncline areas in northern Guizhou of China.

\section{GEOLOGICAL BACKGROUND}

The Anchang syncline at Zheng'an County, Zunyi City, northern Guizhou Province, is tectonically located in the southern section of Wuling-Western Hunan-Hubei fold belt. The research area of Anchang syncline is about $154.63 \mathrm{~km}^{2}$ (Figure 1). Under the multi-stage tectonic compression movements during the late Yanshanian and Himalayan periods, the present "narrow and steep" synclinal structure with complicated by faults was formed in Anchang area. The long axis is very long and the short axis is relatively short in Anchang syncline. The overall structure of Anchang syncline is gentle in the south and west, and is steep in the north and east. After the transformation of Anchang syncline by the overall tectonic movements, small faults are extremely developed in Anchang syncline. Two groups of faults are mainly developed in the NNE and NNW, and the vast majority of faults are not directly linked to the surface.

The main shale gas exploration and development zones in Anchang syncline are Ordovician Wufeng Formation and Silurian Longmaxi Formation. The Wufeng-Longmaxi Formation in Anchang syncline was deposited in the transitional facies between deep water shelf and shallow water shelf. A set of black carbonaceous shales and silty carbonaceous shales with a small amount of thin black siliceous shale are developed in this area. Based on the lithologic and electrical characteristics, the Longmaxi Formation of Anchang syncline can be further divided into Long1 member and Long2 member with a total of five members. The total thickness of Longmaxi Formation is about $29-50 \mathrm{~m}$. The first to the fourth layers are the main target layers with a thickness of 16.9-23.7 m. In plane, the Longmaxi Formation shale in Anchang syncline gradually thickens from south to north.

According to the core observation, there are few structural fractures in this area (Figure 2). The horizontal fractures parallel to the bedding are developed, and most of them are filled with calcite. Among them, fractures are most developed in well Anye C, followed by well Anye B. Fractures are less developed in wells Anye A, Anye E, and Anye D. The measured gas pressure coefficient of Wufeng Formation-Longmaxi Formation in Anchang Syncline is around 0.99 . The measured maximum horizontal principal stress is $45-81 \mathrm{MPa}$, while the minimum horizontal principal stress is 36-64 MPa. The stress difference between these two directions is 9-19 MPa, and the difference coefficient of horizontal stress is about $24.5-35.5 \%$.

\section{PETROPHYSICS PROPERTIES OF SHALES}

\subsection{Minerals and TOC Content}

Taking Well Anye A as an example (Figure 3), the mineral components of Wufeng-Longmaxi Formation shale in Anchang syncline are mainly quartz and clay minerals. Quartz content is 


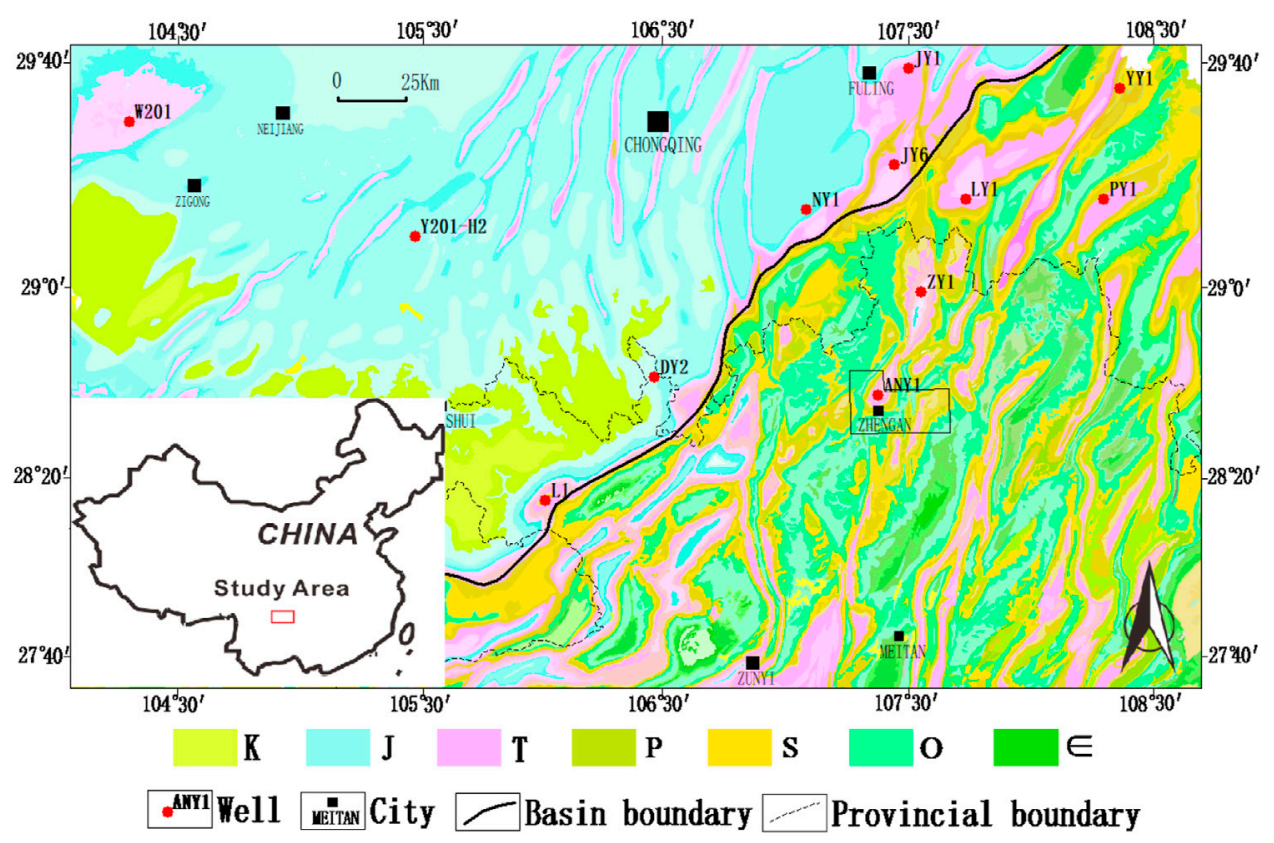

FIGURE 1 | Geological structure of Anchang syncline.

between 22 and $71 \%$ with an average of $54.6 \%$. The average content of carbonate rocks is about $13.6 \%$. The total clay mineral content ranges from 8 to $33 \%$. The total clay mineral content is relatively low, and the average content is less than $20 \%$. The main clay minerals are I/S mixed clays, which accounts for $61.2 \%$ of the total clay minerals. On the whole, gas shales in WufengLongmaxi Formation in Anchang syncline have high content of brittle minerals and low content of clay minerals. The average content of brittle minerals (content, carbonate rocks) is more than $65 \%$ (Table 1).

The kerogen type of Wufeng-Longmaxi shales in Anchang syncline is mainly type I. The thermal maturity of these shales $\left(R_{o}\right)$ is $2.17 \%$ on the average, and it is overmatured to produce dry gas. The total organic carbon (TOC) content of shales is between 3.73 and $4.17 \%$, with an average of $3.98 \%$. The distribution of TOC content is very stable. TOC content of Wufeng-Longmaxi shales decreases slightly from the North to South. Well Anye C in the north of syncline has the highest TOC content, followed by well Anye D in the core of syncline. The lowest TOC content of Wufeng-Longmaxi shales is in well Anye $\mathrm{F}$ in the south of syncline. Overall, TOC content of Wufeng-Longmaxi Formation shales in Anchang syncline is close to that of marine Longmaxi Formation shale in Sichuan Basin (Dai et al., 2014; Yang et al., 2019).

\subsection{Pore Structure Characterization}

Porosity of gas shales in Anchang syncline is between 3.27 and $3.78 \%$, with an average of $3.43 \%$. Average porosity value of shales from well Anye F is the lowest, while that from well Anye D is the highest. Furthermore, porosity of shales from the core of Anchang syncline is slightly higher than that from the wings of the syncline.
Low-temperature liquid nitrogen adsorption isotherms of representative Wufeng-Longmaxi samples in Anchang syncline are illustrated in Figure 4. The BET specific surface derived from adsorption isotherms is between 4.58 and $30.42 \mathrm{~m}^{2} / \mathrm{g}$, with an average of $19.39 \mathrm{~m}^{2} / \mathrm{g}$. The total pore volume averages $0.03 \mathrm{~cm}^{3} / \mathrm{g}$ and the average pore size is $4.39 \mathrm{~nm}$. In general, the BET specific surface area of the Wufeng-Longmaxi Formation shales in the Anchang synclinal is roughly similar to that of the over-pressured Longmaxi Formation shale in the Jiaoshiba area in the Sichuan Basin, while the total pore volume is smaller than the latter (Yang et al., 2019; Xu et al., 2020c). Pore size distributions of representative shales derived from nitrogen adsorption are mainly micropores and fine mesopores (Figure 5). Capillary curves using mercury injection of shale samples have the characteristic of two segments or three segments (Figure 6), and the pore size distributions derived from capillary curves are bimodal. One peak is around $10 \mathrm{~nm}$, while another peak is about $1,000 \mathrm{~nm}$ (Figure 7). This indicates that pore structure of gas shales in this area is variable and irregular, under the influence of atmospheric pressure.

\subsection{Gas Content}

The measured gas content in the field shows that the total gas content of Wufeng Formation and Long1 member of Anchang syncline is between 3.24 and $4.88 \mathrm{~m}^{3} / \mathrm{t}$, with an average of $3.60 \mathrm{~m}^{3} / \mathrm{t}$. Well Anye E has the lowest gas content of $3.24 \mathrm{~m}^{3}$ / t. Wells Anye A and Anye F have the highest gas content, reaching $3.88 \mathrm{~m}^{3} / \mathrm{t}$. The total gas content of Wufeng-Longmaxi Formation shales decreases gradually from bottom formation to top formation. What is more, the total gas content of Wufeng Formation shales is high in the top section and low in bottom section. 


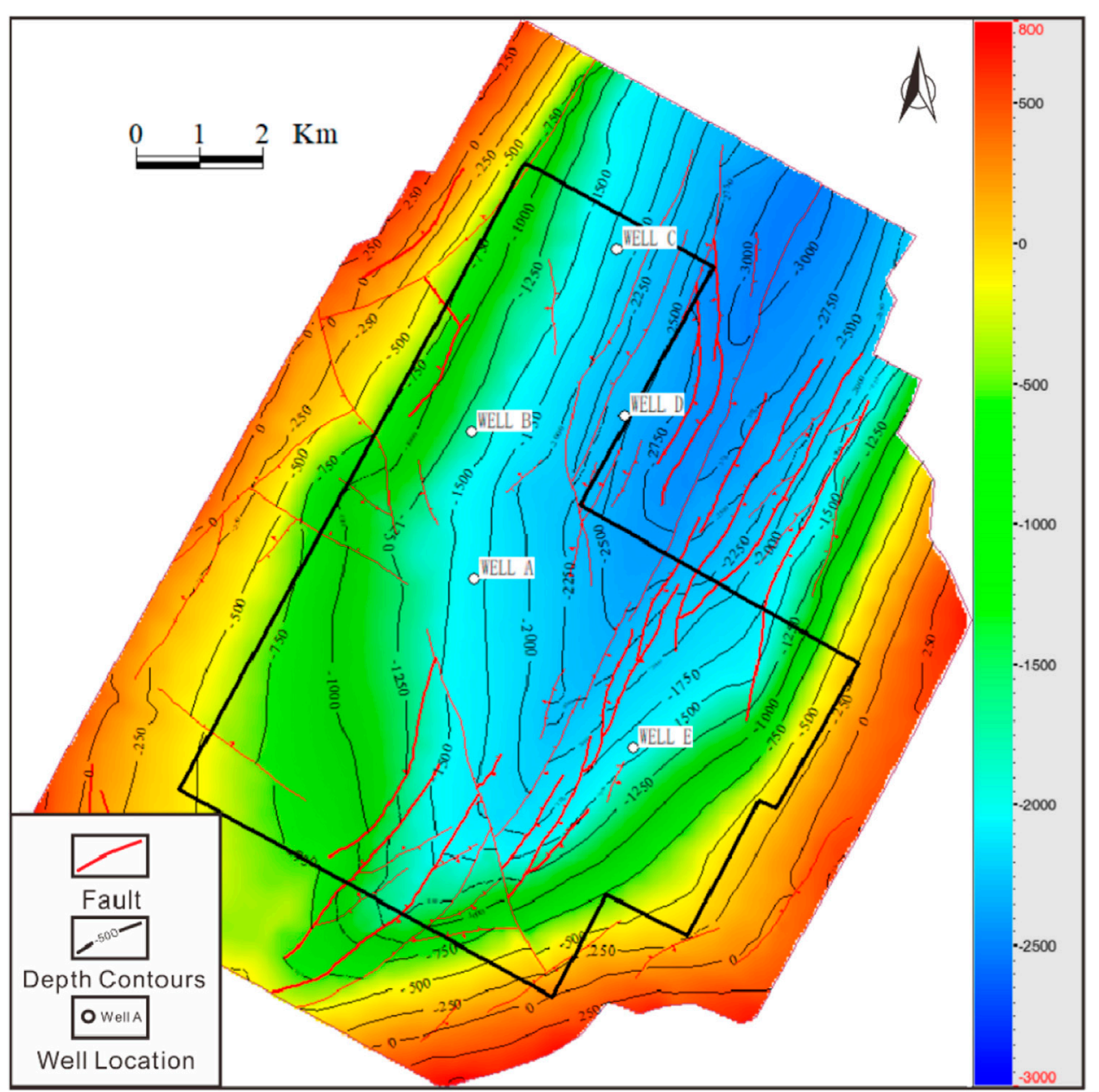

FIGURE 2 | Well locations and main fracture distributions in Anchang syncline.

Based on the minerals, reservoir physical properties, gas content, and geochemical parameters, shales from the 1st-3rd layers in the first member of Longmaxi Formation are classified as type I. Shales from the fourth layers of Wufeng-Longmaxi Formation are type II, while shales from the fifth layers of the Longmaxi Formation are type III. Compared with the surrounding shale gas blocks, the geological conditions of the shale gas reservoirs in the Wufeng-Longmaxi Formation in Anchang area are superior and have the material basis for the formation of large-scaled shale gas reservoirs.

\section{PRESERVATION CONDITIONS OF SHALE GAS RESERVOIR IN ANCHANG SYNCLINE}

The accumulation and enrichment of shale gas is a very complicated geological process. The preservation conditions of shale gas are different from those of conventional natural gas. Here, the preservation conditions of shale gas are analyzed from several different aspects: such as tectonic movements, volcanic activity, and hydrogeological conditions.

\subsection{Hydrogeological Conditions}

Regional hydrodynamics plays an important role in shale gas preservation. When the hydrodynamic force is strong, shale gas will be displaced and the gas reservoir will be destroyed (Yang et al., 2021a). Shale gas can accumulate only when the hydrodynamic force is weak. The chemical property of groundwater is an important index to reflect the hydrodynamic force. The influence of formation water salinity on shale gas preservation conditions is as follows: the higher the salinity, the stronger the formation sealing and the better the preservation conditions (Vidic et al., 2013). The influence of formation water type on shale gas preservation conditions is as follows: the higher the atmospheric water content, the worse the water type and the preservation conditions.

The infiltration depth of paleo-atmospheric water increases from the northwest to southeast in Anchang block, which reflects the uplift amplitude and fault development. These also affect the preservation conditions of shale gas. The mineralization degree of Dengying Formation at $2,410 \mathrm{~m}$ drilled by well FS1 in the adjacent area is $3.981 \mathrm{~g} / \mathrm{L}$, which belongs to $\mathrm{NaHCO}_{3}$ water type (Zhang et al., 2020). The mineralization degree of well 


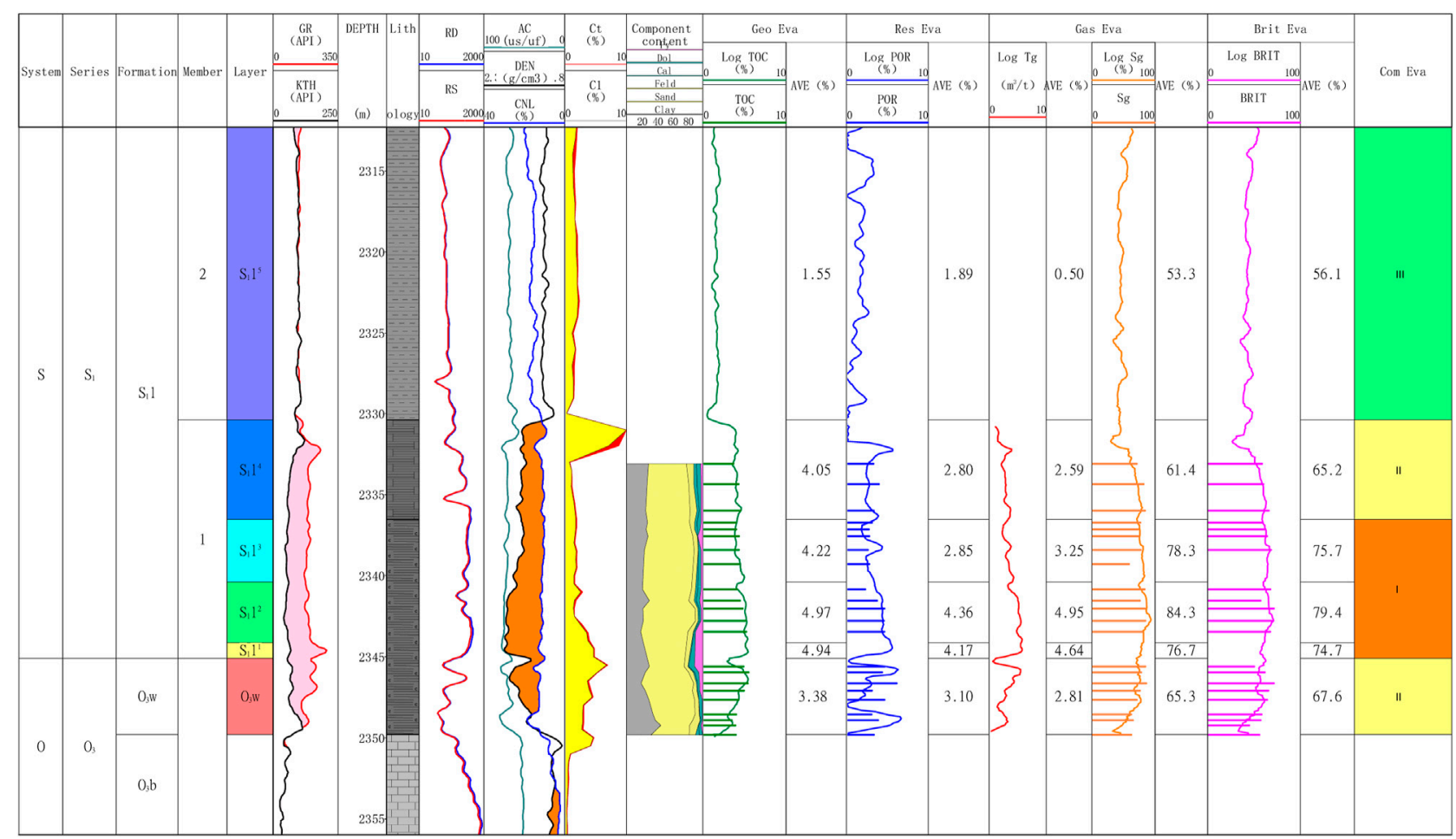

FIGURE 3 | Comprehensive column of well Anye A drilled through the Ordovician Wufeng Formation and Silurian Longmaxi Formation.

TABLE 1 | Petrological and mineralogical characteristics of Wufeng-Longmaxi Formation in Sichuan Basin.

\begin{tabular}{|c|c|c|c|c|c|c|c|}
\hline \multirow[t]{2}{*}{ Well } & \multirow[t]{2}{*}{ TOC (\%) } & \multicolumn{6}{|c|}{ Mineral content } \\
\hline & & Quartz (\%) & Feldspar (\%) & Carbonate (\%) & Pyrite (\%) & Clay (\%) & I/S \\
\hline Well A & 4.43 & 56.9 & 6.4 & 5.9 & 3.3 & 27.5 & 61.2 \\
\hline Well C & 4.02 & 63.8 & 3.2 & 3.4 & 2.1 & 21 & 71.4 \\
\hline Well D & 3.24 & 49 & 4.3 & 11.25 & 2.5 & 15.8 & 61.2 \\
\hline Well E & 4.98 & 56.9 & 4.6 & 2.4 & 3 & 18.1 & 66.1 \\
\hline
\end{tabular}

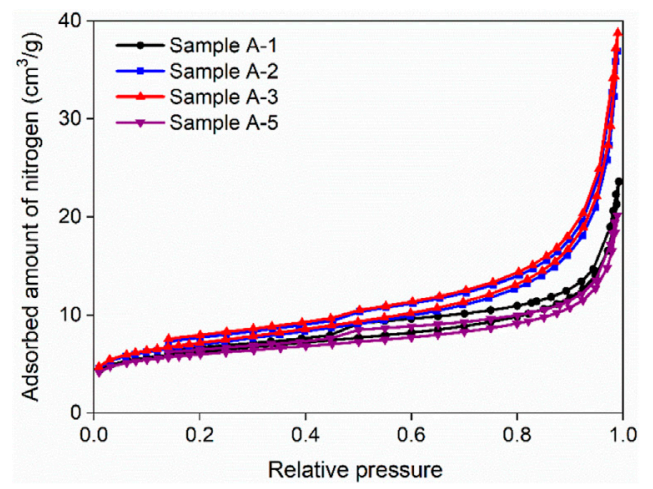

FIGURE 4 | Low-pressure nitrogen adsorption-desorption isotherms of representative shale samples from well Anye A well platform.

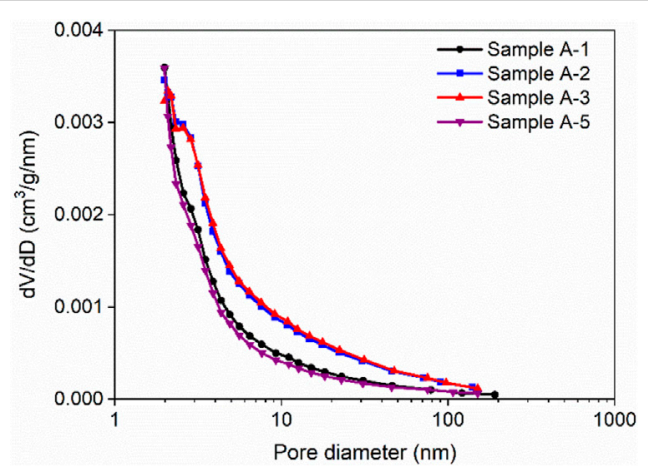

FIGURE 5 | Pore size distribution of representative shale samples from well Anye A well platform derived from nitrogen adsorption isotherms. 


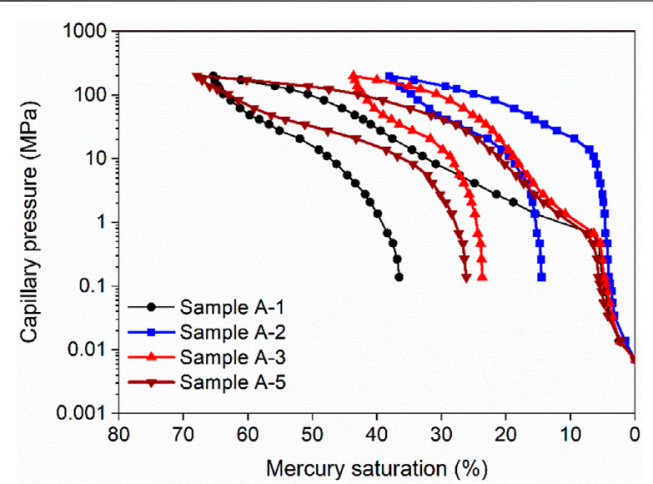

FIGURE 6 | Capillary pressure curves of representative shale samples from well Anye A well platform.

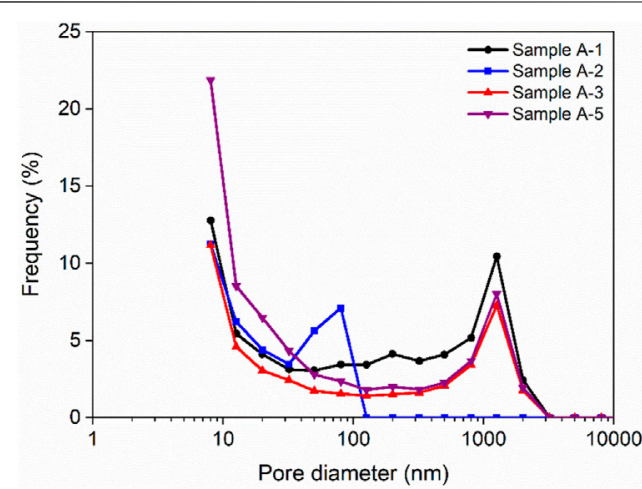

FIGURE 7 | Pore size distribution of representative shale samples from well Anye A well platform derived from capillary pressure curves.

DY1 is less than $3 \mathrm{~g} / \mathrm{L}$ and belongs to $\mathrm{Na}_{2} \mathrm{SO}_{4}$ water type, but there is still fresh water in the cap rocks of the overlying and underlie formations. Shale gas wells drilling through Longmaxi Formation in Pengshui area (PY) are $\mathrm{CaCl}_{2}$ water type, and the Puzi syncline is $\mathrm{CaCl}_{2}-\mathrm{MgCl}_{2}$ water type. According to the typical geochemical indexes of shale gas wells drilled in southeast Chongqing, the groundwater in the surrounding areas of Anchang syncline is of medium salinity and less affected by surface hydrodynamic forces (Table 2). That means that these shale formations have good preservation conditions. Furthermore, considering the large faults and residual synclinal structures developed in southeast Chongqing and the formation water characteristics of Wufeng-Longmaxi Formation, we can summarize the effect of hydrogeological conditions on shale gas preservations: the closer to the core area of Anchang syncline, the weaker influence by the infiltrating of atmospheric water, and the better the preservation conditions for shale gas.

\subsection{Tectonic Preservation Conditions}

Tectonic transformation plays an important role in shale gas preservation, including the tectonic uplift and denudation, stratigraphic occurrence, and burial depth (Xu et al., 2020a; 2020b). The weaker tectonic transformation, the longer uplifting time of the gas reservoir; the more completely developed formation, the farther distance from the opening fault, and the farther the distance from the target emerging area; and the deeper the target layer, the better the shale gas preservation conditions.

The Anchang syncline in northern Guizhou province underwent intense transformation of multi-stage tectonic movements and formed a complex "narrow-steep" syncline structure on the whole. The tectonic faults show the characteristics of being long in the long axis and being short in the short axis. There are mainly three groups of faults: NE (northeast), NNE, and NW (northwest) directions in the area. What is more, the faults in the eastern wing are more developed than the west wing of Anchang syncline. There are total 65 faults according to the seismic interpretation results. Among them, 48 faults have narrow fault spacing of being less than $50 \mathrm{~m}$. Fault system plays a key role in the preservation of shale gas in Anchang syncline. First, the reverse fault located in the up-dip direction of the syncline structure can function as lateral shielding, which prevents gas migration and escape along the up-dip direction of the plane, and preserves shale gas in the favorable area (Figure 8). The seismic prediction results show that there are developed speckle curvatures in the west wing of the syncline. Thus, it is speculated that a large number of fractures are formed, which can effectively improve the storage property and facilitate the high gas production. In contrast, the tensional normal faults developed in the up-dip direction have destructive effects on shale gas preservation. Field tests shows that well Anye D obtained a high initial gas production rate of $53,000 \mathrm{~m}^{3} /$ day, while well Anye $\mathrm{C}$ did not produce any gas at the initial stage of gas test (Figure 2). Secondly, the open faults have adverse effects on gas reservoirs, which mainly occur in the east wing of Anchang syncline. Well Anye E, located in the east wing of Anchang syncline, is close to large faults, and the tested gas production is low. Third, in the area far away from normal faults and open faults, faults have positive effects on gas reservoir preservation. The results show that the fault distance in Anchang syncline is negatively correlated with gas content, maximum tested gas production rate, and average daily gas production. These indicate that the local reverse faults are conducive to high gas content and gas production. According to the test results of drilled shale gas wells at present, the influence degree of faults on the shale gas reservoir in Anchang syncline is as follows: well Anye A > well Anye B > well Anye D > well Anye E > well Anye C.

\subsubsection{Paleo-Uplift and Stratigraphic Depth}

The continuous uplift of the study area since the Indosinian period leads to that a large area of the Triassic strata became outcrop. At the same time, the overlying strata and regional cap rocks above the gas-bearing shales were thinned or denuded, resulting to the destruction of the gas reservoirs (Liu et al., 2020). On one hand, the buried depth of the target layer becomes shallow during the uplift process; on the other hand, with the decreasing of the overburden pressure, the porosity and permeability of the target formation will increase because of 
TABLE 2 | Statistics of average ion content and salinity of formation water of Wufeng-Longmaxi Formation in Sichuan Basin.

\begin{tabular}{|c|c|c|c|c|c|c|c|c|}
\hline \multirow[t]{2}{*}{ Well } & \multirow[t]{2}{*}{ Depth (m) } & \multicolumn{6}{|c|}{ Ion content (g/L) } & \multirow[t]{2}{*}{ Salinity $(g / L)$} \\
\hline & & $\mathrm{K}^{+}+\mathrm{Na}^{+}$ & $\mathrm{Ca}^{2+}$ & $\mathbf{M g}^{2+}$ & $\mathrm{Cl}^{-}$ & $\mathrm{SO}_{4}{ }^{2-}$ & $\mathrm{HCO}_{3}^{-}$ & \\
\hline PY1 & $2,136-2,159$ & 14.851 & 0.776 & 0.076 & 27.705 & 0.234 & 0.376 & 43.98 \\
\hline PY2 & $2,233-2,260$ & 8.546 & 0.392 & 0.048 & 15.095 & 0.040 & 0.549 & 24.64 \\
\hline PY3 & $2,753-2,780$ & 16.085 & 0.830 & 0.072 & 31.102 & 0.104 & 0.376 & 48.58 \\
\hline PY4 & 1899-1915 & 11.354 & 0.600 & 0.071 & 23.928 & 0.068 & 0.289 & 36.28 \\
\hline LY1 & 2,818-2,824 & 11.618 & 0.257 & 0.065 & 11.344 & 9.052 & 0.900 & 33.25 \\
\hline NY1 & 4,399-4,406 & 9.160 & 0.327 & 0.017 & 17.050 & 0.051 & 0.647 & 27.26 \\
\hline JY1 & $2,408-2,419$ & 6.515 & 0.174 & 0.043 & 9.542 & 0.229 & 1.316 & 17.75 \\
\hline JY1-3 & $2,409-2,417$ & 3.625 & 0.205 & 0.104 & 5.026 & 0.473 & 1.514 & 10.90 \\
\hline
\end{tabular}

decreasing stress sensitivity (Yang et al., 2021b). Consequently, the sealing ability of the overburden layer will reduce. The development practice of normal pressure shale gas in Nanchuan shows that the farther away from the outcrops $(>3000 \mathrm{~m})$, the deeper the burial, and the better the preservation conditions of shale gas (Guo, 2013). The eastern wing of the Anchang syncline is close to the stratigraphic denudation area, while the western wing is relatively far away from the denudation area. The distance from the denudation area of shale gas wells in Anchang syncline is listed as: well Anye $\mathrm{A}<$ well Anye $\mathrm{E}<$ well Anye $\mathrm{D}<$ well Anye $\mathrm{B}<$ well Anye $\mathrm{C}$ (Figure 2). In other words, well Anye $\mathrm{C}$ is the farthest from the denudation area, followed by well Anye B. Both well Anye E and well Anye A are close to the denudation areas, which have relatively weak preservation conditions for shale gas reservoirs.

\subsubsection{Dip Angle and Distance From the Outcrop Area}

The tectonic evolution history shows that the uplift time of Anchang area is earlier than Fuling area (Jiaoshiba shale gas field), and the denudation thickness of the studied area is about 2,000-3,000 m, which is similar to that of Pengshui and Fuling area (Xu et al., 2020b). Thus, the amount of escaped shale gas in these areas would be similar. Numerical experiments show that the seepage ability of shales vertical or parallel to the bedding in Anchang area increases significantly at the depth of 1,500-2,000 $\mathrm{m}$ (Zhang et al., 2018). At the same time, the seepage ability also increases significantly with the increasing dip angle of the formation. The larger the dip angle of formation, the higher the gas seepage ability, and the weaker the gas reservoir preservation condition (Zhang et al., 2018). Shale gas seepage ability at the dip angle of $30^{\circ}$ is about six times of that at the dip angle of 5 . What is more, the closer to the outcropping area, the lower the formation pressure, the worse the shale gas preservation conditions, and the lower gas production. The depth of the Longmaxi formation drilled in Anchang area is between $2,500 \mathrm{~m}$ and $3,000 \mathrm{~m}$. The depth of the target formation is moderate, and the distance from the outcrop area is generally $3-5 \mathrm{~km}$. However, the dip angle of the middle wing of Anchang syncline is $25^{\circ}-45^{\circ}$, and that of the west wing is $25-35^{\circ}$. Consequently, shale gas preservation conditions of the five well platforms in Anchang area can be ranked as follows: well Anye D > well Anye A > well Anye B > well Anye E > well Anye

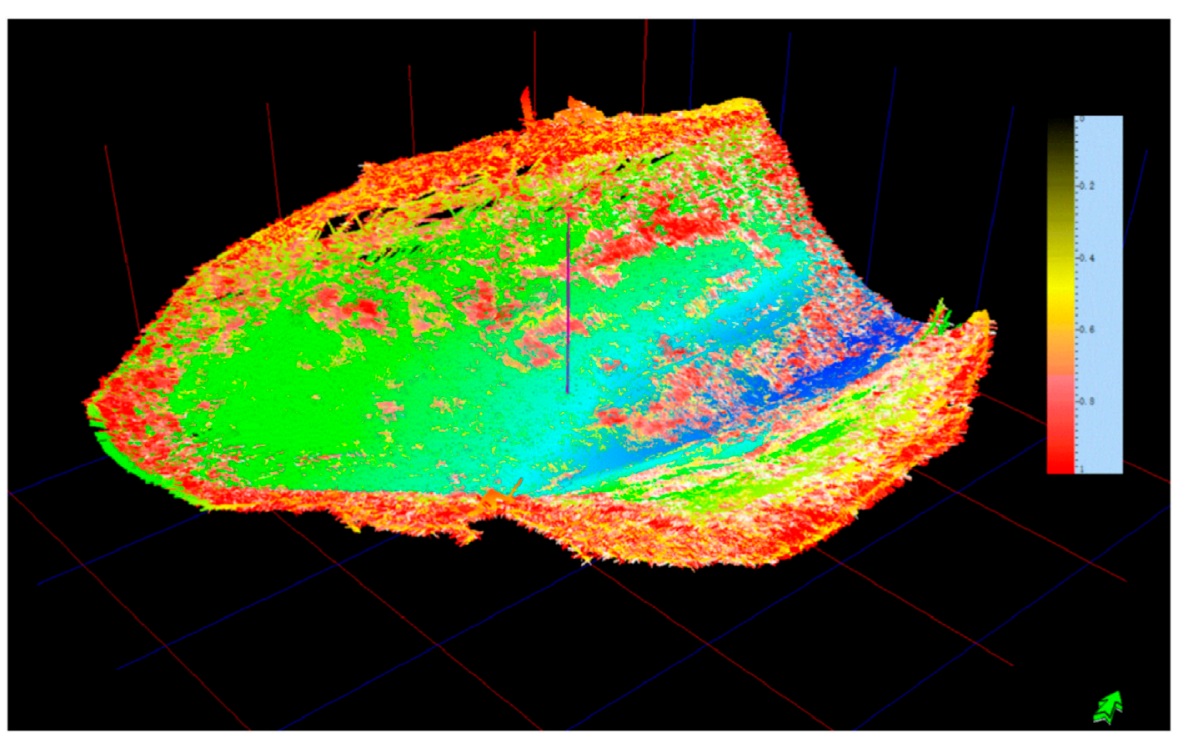

FIGURE 8 | Predicted fractures at the bottom of Wufeng-Longmaxi Formation in well Anye A. 
C, based on the burial depth, formation dip angle, and the distance from the outcrop area.

\subsection{Sealing Ability of Cap Rock and Barrier Layer Rock}

Shale gas systems can be self-sealing. Previous research results show that the interbedding of mudstone, dolomite, and shales is a combined lithology conducive to shale gas preservation (Jarvie et al., 2007). For the area with frequent tectonic movements and high tectonic intensity, the effect of cap rock on shale gas reservoir cannot be ignored (Xu et al., 2020a).

There are mainly two strata with cap rocks developed above the Wufeng Formation-Longmaxi Formation in the study area: Silurian Xintan Formation and Silurian Shiniulan Formation. A set of clastic rocks deposited in the Xintan Formation with a thickness of more than $80 \mathrm{~m}$ during the period of high level system tracts and transgressions system tracts. These clastic rocks are mainly composed of grey-green shale and silty mudstone. Imaging log about these rocks shows that the high conductivity fractures are not developed in the rocks of Xintan Formation, but there are many high resistivity fractures and horizontal bedding. The breakthrough pressure of rocks in Xintan Formation is about 5.9 MPa, indicating good sealing conditions in general (Zhang et al., 2018; Xie et al., 2019). The porosity of the limestones in the Silurian Shiniulan Formation is between 0.3 and $3.9 \%$, and the permeability ranges from 0.001 to $2.1 \mathrm{mD}$. At the same time, the pore size and pore throat radius of the limestones in Shiniulan Formation are even lower than those of shales. What is more, the limestone in the roof and floor of the target layer in the study area has high fracturing pressure, which can be used as the cap of shale gas and form effective barriers for the extension of fractures (Gale et al., 2014). Consequently, the cap conditions of shales in Anchang area are as follows: Anye $\mathrm{C}$ well platform $>$ Anye $\mathrm{E}$ well platform $>$ Anye A well platform $>$ Anye $\mathrm{D}$ well platform $>$ Anye B well platform.

\subsection{Microscopic Fluid Movements}

Shale gas has the characteristics of self-generation and self-reservoir. Unlike the accumulation of conventional natural gas, shale gas accumulation does not require secondary migration. Both migration and accumulation of shale gas occur within the shale strata (Curtis, 2002; Osborn et al., 2011). There are roughly three fluid evolution stages in the process of shale gas accumulation. The first stage is the formation, adsorption, or dissolution of natural gas in the early diagenesis. Secondly, shale gas reservoirs with mainly free gas are formed with the increasing temperature and pressure during the middle and late diagenesis. Third, with the increasing tectonic movements and the generation of more natural gas in the later period, some natural gas escaped (Curtis, 2002; Liu et al., 2021). Anchang area is a typical synclinal structure with normal pressure out of Sichuan basin, and shale gas migration firstly occurs in the process of accumulation. The lateral migration of shale gas from the generation stratum to the shallow buried stratum is influenced by the tectonic uplift, denudation, as well as groundwater activities (Hammond et al., 2020; Bondu et al., 2021). The difference of burial depth and pore fluid pressure in different parts of Anchang syncline may reflect the difference of shale gas lateral migration. This differential migration of gas leads to the shale gas loss, but also contributes to the accumulation of shale gas in the core area of syncline. The superior cap rock conditions and the favorable microscopic properties of the reservoir guarantee the higher gas abundance of the reservoir.

\section{DISCUSSION}

\subsection{Accumulation Pattern of Shale Gas in Anchang Area}

Anchang area has unique geological background, superior reservoir quality, and good shale gas formation conditions and materials foundation, which lays a foundation for the rich accumulation of shale gas. The accumulation conditions in the later stage determine the enrichment pattern of shale gas sweet spots in Anchang area. There are mainly three aspects related to the enrichment pattern of shale gas in Anchang area (Figure 9):

1) The enrichment of shale gas in Anchang syncline is controlled by sedimentary facies and preservation conditions. The study area was deposited in shallow water shelf to deep water shelf sedimentary environment. Under the unique geological background of shallow burial and residual transformation, Wufeng-Longmaxi shales in Anchang syncline have excellent organic matter parameters (mainly type I organic matter, high TOC content, moderate $\mathrm{R}_{\mathrm{o}}$ ), well developed pores, high gas content and high content of brittle minerals.

2) The preservation conditions of shale gas are extremely complex. The tectonic conditions (uplift and fault), volcanic activities, sealing properties, groundwater activities, and microscopic properties of the reservoir comprehensively control the migration, accumulation, and preservation of shale gas. The target layer was deposited in the process of ascending current, which promoted the enrichment of organic matter. During the multiple tectonic movements, there are weak uplifts in the early stage, stable settlement for a long time, and strong reconstruction in the late stage in Anchang syncline, which causes the strata uplift and extrusion rupture, and shale gas loss partly. The activity of groundwater leads to shale gas loss on one hand, but also facilitates the accumulation of shale gas in the core part of Anchang syncline. The superior cap rock and the favorable microscopic properties of the reservoir ensure the high gas content of the reservoir in Anchang area.

3) The syncline structure, fault distribution, lithology, and hydrologic conditions comprehensively control the pressure distribution and gas content of shale reservoir. These form a special accumulation model of "syncline controlling reservoir area, fault controlling the edge, preservation controlling gas content". The distribution of shale gas in Anchang syncline has the typical characteristics: shale gas stores in deep position, moderately accumulates in the wings, and enriches in core area.

\subsection{Identification of Sweet Spot and Drilling Results}

The enrichment of shale gas reservoir is limited by the preservation conditions in the plane. By the combination of shale gas production 


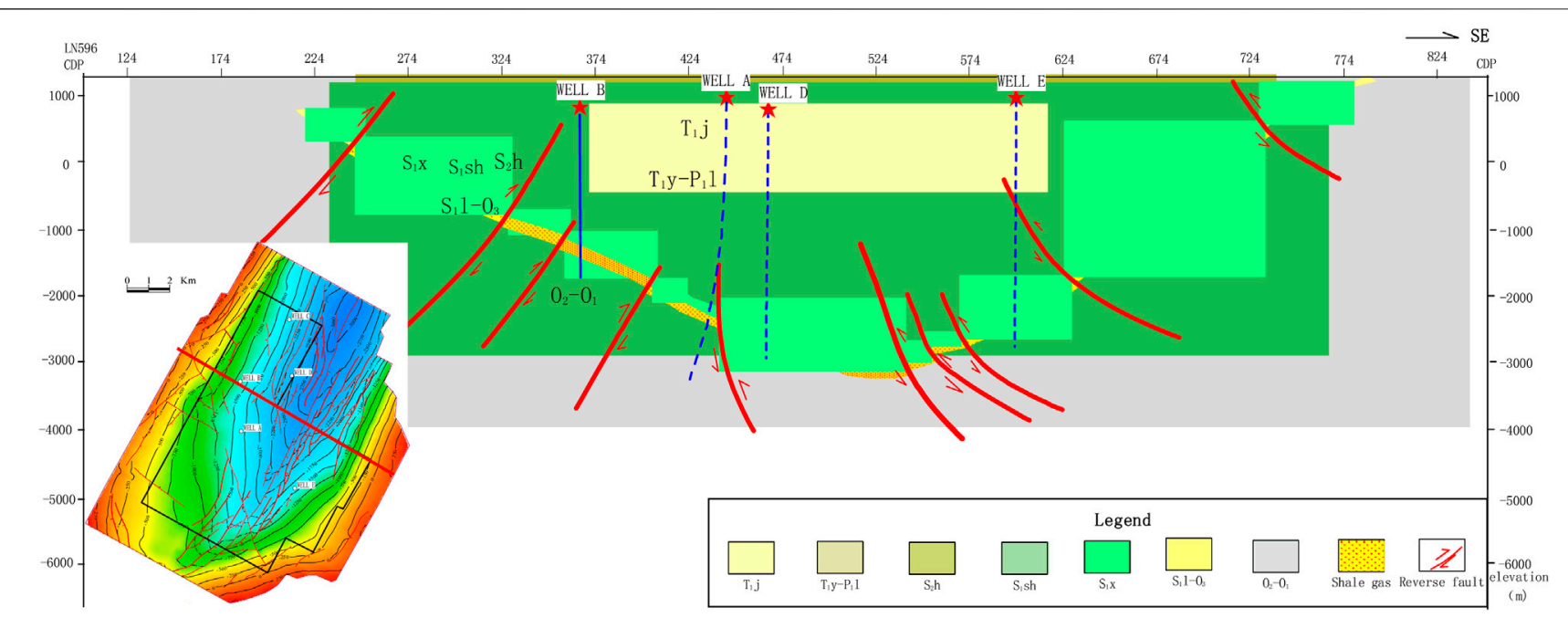

FIGURE 9 | The differential enrichment model of shale gas in upper Ordovician-Lower Silurian Wufeng-Longmaxi Formation in Anchang syncline.

practice in the adjacent regions, buried depth, dip angle, and the distance from the denudation, an evaluation standard for the preservation conditions of atmospheric shale gas in Anchang block is systematically established: 1) the core area is the priority for shale gas development, and then the gentle wing. The steep slope should be treated with great deliberation. 2) The thrust faults, especially the thrust fault with small dip, own a shielding effect, which is conducive to shale gas accumulation. 3) The groundwater stagnation zone, which is far away from the outcrop area, is the most favorable target area. The distance from the outcrop area should be larger than $1.5 \mathrm{~km}$. The far distance from the outcrop, the better preservation condition. 4) Micro-fractures are conducive to improve shale gas accumulation.

According to the proposed evaluation criteria of shale gas preservation conditions, a total area of $58.71 \mathrm{~km}^{2}$ is selected as the optimal favorable area in Anchang area. Based on the evaluation results of the above favorable areas and the principles of favorable preservation conditions, a third round of geological design and implementation of horizontal wells were carried out. From the perspective of gas tests, the tested results of the third round of horizontal well considering the sweet spot were significantly improved, compared with the first two rounds. The average daily production increased from $14200 \mathrm{~m}^{3} /$ day to $26200 \mathrm{~m}^{3}$ / day per well. The self-gusher capacity of the gas test well increases obviously, which proves the effectiveness of the proposed enrichment rule and the accumulation model.

\section{CONCLUSION}

This study investigates the enrichment and accumulation of normal pressure shale gas in Anchang syncline outside of Sichuan Basin. A comprehensive analysis is conducted according to the geological information, organic chemistry data, petrophysical data, and mineral compositions. The geological characteristics of shales in Anchang syncline are also compared to the adjacent region in
Sichuan Basin. Consequently, an accumulation pattern of shale gas reservoir with normal gas pressure is proposed. The main conclusions can be drawn:

1) Plenty of carbonaceous shales in Wufeng-Longmaxi Formation of Anchang syncline in northern Guizhou province were deposited in the transitional environment between deep water shelf and shallow water shelf. This shale gas reservoir has excellent static quality, but is strongly transformed by multi-stage tectonic movements. There is an asymmetric compressional syncline structure in Anchang area, and thus, many small faults and microtectonics develop in this area. The stratigraphic dip angle in Anchang syncline varies a lot. The gas-bearing characteristic of different tectonic units also differs greatly.

2) The enrichment of shale gas reservoirs in Wufeng-Longmaxi Formation of Anchang syncline are mainly determined by the sedimentary facies and the structural preservation conditions. Among which, the preservation conditions are critical to the enrichment and high yield of shale gas. Through the analysis of tectonic characteristics of typical well platforms, paleo-tectonic uplift and denudation, hydrogeological conditions, and other factors, the enrichment rule and accumulation model of shale gas in this area are established. Based on this, the favorable shale gas sweet spots are delineated, which effectively guide the rolling deployment of horizontal wells in this area.

3) The research results about the enrichment rules of shale gas mainly focus on the geological information. It is partly drawn according to the experience of neighboring areas, and without considering the influence of engineering technology factors. The efficient development of shale gas requires the combination of geological knowledge and engineering technology. Further research is suggested to combine the geological analysis and engineering technology. These researches may include a detailed analysis of hydrogeological conditions, inversion study of reservoir 
parameters based on drainage characteristics, geological and engineering suitability study of small-diameter proppant to control fracture diversion, and enhanced drainage. Through these systematic investigations, the development effects of shale gas with normal pressure will be considerably improved.

\section{DATA AVAILABILITY STATEMENT}

The original contributions presented in the study are included in the article/supplementary material. Further inquiries can be directed to the corresponding authors.

\section{REFERENCES}

Aguilera, R. (2016). Shale Gas Reservoirs: Theoretical, Practical and Research Issues. Pet. Res. 1 (1), 10-26. doi:10.1016/s2096-2495(17)30027-3

Bai, B., Elgmati, M., Zhang, H., and Wei, M. (2013). Rock Characterization of Fayetteville Shale Gas Plays. Fuel 105, 645-652. doi:10.1016/j.fuel.2012.09.043

Bondu, R., Kloppmann, W., Naumenko-Dèzes, M. O., Humez, P., and Mayer, B. (2021). Potential Impacts of Shale Gas Development on Inorganic Groundwater Chemistry: Implications for Environmental Baseline Assessment in Shallow Aquifers. Environ. Sci. Technol. 55 (14), 9657-9671. doi:10.1021/acs.est.1c01172

Curtis, J. B. (2002). Fractured Shale-Gas Systems. AAPG Bull. 86, 1921-1938. doi:10.1306/61eeddbe-173e-11d7-8645000102c1865d

Dai, J., Zou, C., Liao, S., Dong, D., Ni, Y., Huang, J., et al. (2014). Geochemistry of the Extremely High thermal Maturity Longmaxi Shale Gas, Southern Sichuan Basin. Org. Geochem. 74, 3-12. doi:10.1016/j.orggeochem.2014.01.018

Fang, Z. X., and He, X. P. (2016). Formation and Evolution of normal Pressure Shale Gas Reservoir in Wulong Syncline, Southeast Chongqing, China[J]. Oil Gas Geology. 37 (6), 819-827. doi:10.11743/ogg20160603

Gale, J. F. W., Laubach, S. E., Olson, J. E., Eichhuble, P., and Fall, A. (2014). Natural Fractures in Shale: A Review and New Observations. Bulletin 98, 2165-2216. doi:10.1306/08121413151

Guo, T. (2013). Evaluation of Highly Thermally Mature Shale-Gas Reservoirs in Complex Structural Parts of the Sichuan Basin. J. Earth Sci. 24, 863-873. doi:10.1007/s12583-013-0384-4

Guo, T., and Zhang, H. (2014). Formation and Enrichment Mode of Jiaoshiba Shale Gas Field, Sichuan Basin. Pet. Explor. Dev. 41, 28-36. doi:10.1016/s18763804(14)60003-3

Hammond, P. A., Wen, T., Brantley, S. L., and Engelder, T. (2020). Gas Well Integrity and Methane Migration: Evaluation of Published Evidence during Shale-Gas Development in the USA. Hydrogeol J. 28, 1481-1502. doi:10.1007/ s10040-020-02116-y

Hao, F., Zou, H., and Lu, Y. (2013). Mechanisms of Shale Gas Storage: Implications for Shale Gas Exploration in China. Bulletin 97, 1325-1346. doi:10.1306/ 02141312091

He, X., Qi, Y., He, G., Gao, Y., Liu, M., Zhang, P., et al. (2019). Further Understanding of Main Controlling Factors of normal Pressure Shale Gas Enrichment and High Yield in the Area with Complex Structure of the Southeast Area of Chongqing. Reserv. Evaluat. Dev. 9 (5), 32-39. doi:10.13809/j.cnki.cn32-1825/te.2019.05.004

Huang, R. B., Wei, X. F., and Wang, Q. (2017). Key Factors of Shale Gas Accumulation in Dingshan Area of southeastern Sichuan Basin[J]. Mar. Origin Pet. Geology. 22 (2), 25-30. doi:10.3969/j.issn.1672-9854.2017.02.004

Jarvie, D. M., Hill, R. J., Ruble, T. E., and Pollastro, R. M. (2007). Unconventional Shale-Gas Systems: The Mississippian Barnett Shale of north-central Texas as One Model for Thermogenic Shale-Gas Assessment. Bulletin 91 (4), 475-499. doi:10.1306/12190606068

Jin, Z., Hu, Z., Gao, B., and Zhao, J. (2016). Controlling Factors on the Enrichment and High Productivity of Shale Gas in the WufengLongmaxi Formation, southeastern Sichuan Basin. Earth Sci. Front. 23 (1), 1-10.

Liu, R., Hao, F., Engelder, T., Zhu, Z., Yi, J., Xu, S., et al. (2020). Influence of Tectonic Exhumation on Porosity of Wufeng-Longmaxi Shale in the Fuling Gas

\section{AUTHOR CONTRIBUTIONS}

BL: writing-reviewing and editing; SL: conceptualization, methodology, and software; HJ: supervision; SL: visualization and investigation. FZ and $\mathrm{ZZ}$ : visualization and investigation.

\section{FUNDING}

This work is supported by the Guizhou Geological Exploration Foundation (No. 208-9912-JBN-L1D7) and Guizhou Science and Technology Support Foundation (2021MA6EBN2P022541).

Field of the Eastern Sichuan Basin, China. Bulletin 104 (4), 939-959. doi:10.1306/08161918071

Liu, R., Wen, T., Amalberti, J., Zheng, J., Hao, F., Jiang, D., et al. (2021). The Dichotomy in noble Gas Signatures Linked to Tectonic Deformation in Wufeng-Longmaxi Shale, Sichuan Basin. Chem. Geology. 581, 120412. doi:10.1016/j.chemgeo.2021.120412

Osborn, S. G., Vengosh, A., Warner, N. R., and Jackson, R. B. (2011). Methane Contamination of Drinking Water Accompanying Gas-Well Drilling and Hydraulic Fracturing. Proc. Natl. Acad. Sci. 108 (20), 8172-8176. doi:10.1073/pnas.1100682108

R. Rezaee (Editor) (2015). Fundamentals of Gas Shale Reservoirs (Perth, WA: John Wiley \& Sons).

Vidic, R. D., Brantley, S. L., Vandenbossche, J. M., Yoxtheimer, D., and Abad, J. D. (2013). Impact of Shale Gas Development on Regional Water Quality. Science 340, 1235009. doi:10.1126/science.1235009

Xiao, X.-M., Wei, Q., Gai, H.-F., Li, T.-F., Wang, M.-L., Pan, L., et al. (2015). Main Controlling Factors and Enrichment Area Evaluation of Shale Gas of the Lower Paleozoic marine Strata in south China. Pet. Sci. 12, 573-586. doi:10.1007/ s12182-015-0057-2

Xie, G., Liu, S., Xia, G., and Hao, W. (2019). Mineralogy and Geochemical Investigation of Cambrian and Ordovician-Silurian Shales in South China: Implication for Potential Environment Pollutions. Geol. J. 55 (1), 477-500. doi:10.1002/gj.3414

Xu, S., Gou, Q., Hao, F., Zhang, B., Shu, Z., Lu, Y., et al. (2020a). Shale Pore Structure Characteristics of the High and Low Productivity wells, Jiaoshiba Shale Gas Field, Sichuan Basin, China: Dominated by Lithofacies or Preservation Condition? Mar. Pet. Geology. 114, 104211. doi:10.1016/ j.marpetgeo.2019.104211

Xu, S., Gou, Q., Hao, F., Zhang, B., Shu, Z., and Zhang, Y. (2020b). Multiscale Faults and Fractures Characterization and Their Effects on Shale Gas Accumulation in the Jiaoshiba Area, Sichuan Basin, China. J. Pet. Sci. Eng. 189, 107026. doi:10.1016/j.petrol.2020.107026

Xu, S., Hao, F., Shu, Z., Zhang, A., and Yang, F. (2020c). Pore Structures of Different Types of Shales and Shale Gas Exploration of the Ordovician Wufeng and Silurian Longmaxi Successions in the Eastern Sichuan Basin, South China. J. Asian Earth Sci. 193, 104271. doi:10.1016/j.jseaes.2020.104271

Xu, S., Liu, R., Hao, F., Engelder, T., Yi, J., Zhang, B., et al. (2019). Complex Rotation of Maximum Horizontal Stress in the Wufeng-Longmaxi Shale on the Eastern Margin of the Sichuan Basin, China: Implications for Predicting Natural Fractures. Mar. Pet. Geology. 109, 519-529. doi:10.1016/ j.marpetgeo.2019.06.008

Yang, F., Lyu, B., and Xu, S. (2021a). Water Sorption and Transport in Shales: An Experimental and Simulation Study. Water Resour. Res. 57, e2019WR026888. doi:10.1029/2019wr026888

Yang, F., Xu, S., Hao, F., Hu, B., Zhang, B., Shu, Z., et al. (2019). Petrophysical Characteristics of Shales with Different Lithofacies in Jiaoshiba Area, Sichuan Basin, China: Implications for Shale Gas Accumulation Mechanism. Mar. Pet. Geology. 109, 394-407. doi:10.1016/j.marpetgeo.2019.06.028

Yang, F., Zheng, H., Lyu, B., Wang, F., Guo, Q., and Xu, H. (2021b). Experimental Investigation about Gas Transport in Tight Shales: An Improved Relationship between Gas Slippage and Petrophysical Properties. Energy Fuels 35 (5), 3937-3950. doi:10.1021/acs.energyfuels.0c04086 
Zagorski, W. A., Wrightstone, G. R., and Bowman, D. C. (2012). “The Appalachian Basin Marcellus Gas Play: Its History of Development, Geologic Controls on Production, and Future Potential as a World-Class Reservoir," in Shale Reservoirs -Giant Resources for the 21st century. Editor J. A. Breyer (Canonsburg, Pennsylvania: AAPG Memoir), 97, 172-200.

Zhang, G., Nie, H., Tang, X., Du, W., Sun, C., and Chen, S. (2020). Pyrite Type and its Effect on Shale Gas Accumulation: a Case Study of Wufeng-Longmaxi Shale in Sichuan Basin and its Periphery. Petrol. Geol. Exp. 42 (3), 459-466. doi:10.11781/sysydz202003459

Zhang, K., Jiang, Z. X., Xie, X. L., Gao, Z., Liu, T., Yin, L., et al. (2018). Lateral Percolation and its Effect on Shale Gas Accumulation on the Basis of Complex Tectonic Background. Geofluids 2018, 5195469. doi:10.1155/ 2018/5195469

Zheng, H. R., Peng, Y. M., Tang, J. X., Long, S. X., Liu, G. X., Gao, G. X., et al. (2019). Exploration Prospect of Normal Pressure Shale Gas in Middle and UpperYangtze Regions: A Case Study of the Lower Cambrian Shale inXiangzhong Depression[J]. Oil Gas Geology. 40 (6), 1155-1167. doi:10.11743/ogg20190601

Zumberge, J., Ferworn, K., and Brown, S. (2012). Isotopic Reversal ('rollover') in Shale Gases Produced from the Mississippian Barnett and Fayetteville Formations[J]. Mar. Pet. Geology. 31 (1), 43-52. doi:10.1016/j.marpetgeo.2011.06.009
Conflict of Interest: Authors BF, FZ, SL, HJ and SL employed by the company Wujiang Energy Group Company Guizhou Energy Industry Research Institute Co., Ltd.

The remaining authors declare that the research was conducted in the absence of any commercial or financial relationships that could be construed as a potential conflict of interest.

Publisher's Note: All claims expressed in this article are solely those of the authors and do not necessarily represent those of their affiliated organizations, or those of the publisher, the editors and the reviewers. Any product that may be evaluated in this article, or claim that may be made by its manufacturer, is not guaranteed or endorsed by the publisher.

Copyright (C) 2022 Lan, Zhao, Li, Jiang, Liu and Zhang. This is an open-access article distributed under the terms of the Creative Commons Attribution License (CC BY). The use, distribution or reproduction in other forums is permitted, provided the original author(s) and the copyright owner(s) are credited and that the original publication in this journal is cited, in accordance with accepted academic practice. No use, distribution or reproduction is permitted which does not comply with these terms. 